\title{
MENGUKUR TINGKAT PARTISIPASI PEMUDA DALAM PROGRAM KARANG TARUNA DENGAN PENDEKATAN METODE FUZZY INFRENCE SYSTEM MAMDANI
}

\author{
Imam Sunoto \\ Fakultas Teknik Matematika dan IPA, Program Studi Teknik Informatika \\ Universitas Indraprasta PGRI \\ Email: raidersimam@gmail.com \\ Ade Lukman Nulhakim \\ Fakultas Teknik Matematika dan IPA, Program Studi Teknik Informatika \\ Universitas Indraprasta PGRI \\ Email: vlh1330@gmail.com
}

\begin{abstract}
ABSTRAK
Karang Taruna adalah suatu organisasi kepemudaan yang ada di Indonesia dan merupakan sebuah wadah tempat pengembangan jiwa sosial generasi muda, Karang Taruna tumbuh atas kesadaran dan rasa tanggung jawab sosial dari masyarakat dan untuk masyarakat itu sendiri khususnya generasi muda yang ada di suatu wilayah desa, kelurahan atau komunitas sosial yang sederajat, terutama bergerak pada bidang-bidang kesejahteraan sosial. Seperti dalam bidang ekonomi, olahraga, keterampilan, keagamaan dan keseniansesuai dengan tujuan didirikannya Karang Taruna untuk memberikan pembinaan dan pemberdayaan kepada para remaja yang ada di dalam suatu desa atau wilayah itu sendiri. Karang Taruna adalah wadah atau wahana pembinaan generasi muda, untuk dapat tumbuh dan berkembang sesuai dengan potensi dan kemampuanya. Dengan wadah tersebut diharapkan generasi muda mempunyai rasa tanggungjawab yang besar terhadap diri sendiri, sosial dan masyarakat. Dengan demikian generasi muda dapat berpartisipasi dalam pembangunan dengan baik. Dalam mendukung kegiatan masyarakat untuk mencapai suatu tujuan merupakan keinginan semua masyarakat. Untuk itu dibutuhkan suatu sistem yang dapat mengukur tingkat partisipasi pemuda dalam program Karang Taruna dilihat dari aspek pengelolaan program. Dalam penelitian ini menggunakan metode fuzzy infrence system (fis) Mamdani. Dengan adanya sistem pengukuran tersebut diharapkan dapat memudahkan pihak Karang Taruna dalam mengkur tingkat partisipasi pemuda dalam program Karang Taruna dilihat dari aspek pengelolaan program dengan lebih cepat dan akurat sesuai dengan kondisi dari pemuda di lingkungannya. Hasil dari penelitian ini yaitu berupa prototipe yang dapat memproses masukan berupa pengukuran tingkat partisipasi dalam pemanfaatan, pelaksanaan, dan perencanaan kegiatan Karang Taruna.
\end{abstract}

Kata kunci: FIS mamdani, pemuda, partisipasi, karang taruna.

\begin{abstract}
Karang Taruna is a youth organization that exist in Indonesia and is a place where the development of social life of the young generation, Karang Taruna grows on the awareness and sense of social responsibility of the community and for the community itself, especially the younger generation in a village area, kelurahan or an equitable social community, primarily engaged in the areas of social welfare. As in the field of economy, sports, skills, religion and art in accordance with the purpose of establishment of youth community to provide coaching and empowerment to the teenagers within a village or region itself, Karang Taruna is a container or vehicle for young generation to grow and develop in accordance with its potential and capability. With the container is expected young people have a great sense of responsibility towards themselves, social and community. Thus the younger generation can participate in development well. In support of activities in society to achieve a goal is the desire of all people. For that we need a system that can measure the level of youth participation in the program Karang Taruna seen from the aspects of program management. In this research using fuzzy infrence system (fis) Mamdani method. Given the measurement system is expected to facilitate the Karang Taruna in mengur level of youth participation in the program Karang Taruna seen from the aspects of program management more quickly and accurately in accordance with the conditions of youth in the environment. The result of this research is a prototype that can process input in the form of measurement of participation level in utilization, implementation, and planning of Karang Taruna activity.
\end{abstract}

Keywords: FIS mamdani, youth, participation, karang taruna. 


\section{PENDAHULUAN}

\subsection{Latar Belakang}

Organisasi-organisasi pemuda yang ada di Indonesia bertujuan untuk menghimpun tenaga remaja dan menyalurkannya ke dalam kesibukan yang produktif. Penyalahgunaan daripada keadaan ini sudah barang tentu ada, yaitu bila pemimpin-pemimpin himpunan pemuda menggunakan pengaruhnya untuk kepentingan diri sendiri dan mengarahkan kelompoknya untuk maksud-maksud yang kurang baik. Tetapi dalam keadaan yang normal maka himpunan atau organisasi pemuda yang ada, di samping bermanfaat untuk memberikan sumbangan dalam pembangunan negaranya, juga berfungsi sebagai pengembangan sikap sosial remaja.

Karang Taruna adalah suatu organisasi Kepemudaan yang ada diIndonesia dan merupakan sebuah wadah tempat pengembangan jiwa sosial generasi muda, Karang Taruna tumbuh atas kesadaran dan rasa tanggungjawab sosial dari masyarakat dan untuk masyarakat itu sendiri khususnya generasi muda yang ada di suatu wilayah desa, kelurahan atau komunitas sosial yang sederajat, terutama bergerak pada bidang-bidang kesejahteraan sosial [1]. Seperti dalam bidang ekonomi, olahraga, keterampilan, keagamaan dan keseniansesuai dengan tujuan didirikannya karang taruna untuk memberikan pembinaan dan pemberdayaan kepada para remaja yang ada di dalam suatu desa atau wilayah itu sediri, sebagai organisasi sosial kepemudaan Karang Taruna merupakan wadah atau tempat pembinaan dan pengembangan dalam upaya mengembangkan kegiatan ekonomi, sosial, budaya dengan pemanfaatan semua potensi yang ada di lingkungan masyarakat baik sumber daya manusia dan sumber daya alam itu sendiri yang telah tersedia.

Karang Taruna adalah wadah atau wahana pembinaan generasi muda, untuk dapat tumbuh dan berkembang sesuai dengan potensi dan kemampuanya [2]. Dengan wadah tersebut diharapkan generasi muda mempunyai rasa tanggungjawab yang besar terhadap diri sendiri, sosial dan masyarakat. Dengan demikian generasi muda dapat berpartisipasi dalam pembangunan dengan baik. Dalam mendukung kegiatan dalam masyarakat untuk mencapai suatu tujuan merupakan keinginan semua masyarakat. Untuk itu didirikanlah organisasi untuk mewujudkan suatu keinginan yang ingin dicapai. Organisasi juga diperlukan untuk mengkordinasikan segala sumber-sumber yang ada untuk mendapatkan hasil yang maksimal. Organisasi Karang Taruna ini seharusnya mendapatkan perhatian lebih dari masyarakat, pemerintah serta pihak-pihak yang terkait. Dikarenakan akhir-akhir ini banyak pemuda-pemudi yang kurang mendapatkan perhatian serta sulitnya untuk mengekspresikan diri, sehingga kita dapat melihat apa yang remaja lakukan saat ini adalah hal-hal yang tidak diharapkan oleh semua pihak.

Namun, pada kenyataannya masih banyak pemuda yang tidak peduli atau tidak tanggap oleh kegiatan-kegiatan pemuda, misal pemuda yang bekerja atau meneruskan pendidikannya diluar daerah, sehingga membuat mereka tak acuh terhadap kegiatan Karang Taruna, pemuda yang mengalami pernikahan dini lebih banyak watunya untuk mengurus rumah tangga mereka. Laju pertumbuhan ekonomi suatu negara ditopang oleh perekonomian suatu daerah ditentukan oleh keluarga sebagai basis dari sebuah keluarga merupakan syarat utama dari berkembangnya ketahanan ekonomi. Produktivitas ekonomi harus sesuai dengan potensi yang ada di dalam masyarakat, sehingga arah kebijakan yang akan dibuat mampu melihat realitas yang ada di dalam masyarakat [3].

\subsection{Pengertian Sistem Pendukung Keputusan}

Sistem adalah suatu kesatuan usaha yang terdiri dari bagian-bagian yang berkaitan satu sama lain yang berusaha mencapai suatu tujuan dalam suatu lingkungan kompleks. Pengertian tersebut mencerminkan adanya beberapa bagian dan hubungan antara bagian, ini menunjukkan kompleksitas dari sistem yang meliputi kerja sama antara bagian yang independent satu sama lain. Selain itu dapat dilihat bahwa sistem berusaha mencapai tujuan. Pencapaian tujuan ini menyebabkan timbulnya dinamika, perubahan-perubahan yang terus-menerus perlu dikembangkan dan dikendalikan [4].

Sistem pendukung keputusan sebagai sekumpulan prosedur berbasis model untuk data pemrosesan dan penilaian guna membantu para manajer mengambil keputusan untuk sukses, sistem tersebut haruslah sederhana, cepat, mudah dikontrol, adaptif lengkap dengan isu-isu penting, dan mudah berkomunikasi [5]. Dari definisi tersebut, dapat diindikasikan empat karakteristik utama dari sistem pendukung keputusan, yaitu:

a) Sistem pendukung keputusan menggabungkan data dan model menjadi satu bagian.

b) Sistem pendukung keputusan dirancang untuk membantu para manajer (pengambil keputusan) dalam proses pengambil keputusan dari masalah yang bersifat semi struktural (tidak terstruktur).

c) Sistem pendukung keputusan lebih cenderung dipandang sebagai penunjang penilaian manajer dan sama sekali bukan untuk menggantikannya. 
d) Teknik sistem pengambil keputusan dikembangkan untuk meningkatkan efektivitas dari pengambil keputusan.

Aplikasi dari sistem pengambil keputusan baru dapat dikatakan berhasil atau bermanfaat, jika terdapat kondisi sebagai berikut:

a) Eksistensi dari basis data yang sangat besar, sehingga sulit mendayagunakannya.

b) Kepentingan adanya transformasi dan komputasi pada proses pencapaian keputusan.

c) Adanya keterbatasan waktu, baik dalam penentuan hasil maupun dalam prosesnya.

d) Kepentinganakan penilaian atas pertimbangan akal sehat untuk menentukan dan mengetahui pokok permasalahan, serta pengembangan alternatif dan penilain solusi.

\subsection{Rumusan Masalah}

Dari latar belakang diatas maka didapatkan rumusan masalah yaitu bagaimana mengukur tingkat partisipasi pemuda dalam program Karang Taruna Desa Saga Kecamatan Balaraja Kabupaten Tangerang Provinsi Banten dilihat dari aspek pengelolaan program?

\subsection{Tujuan}

Berdasarkan rumusan masalah di atas, maka tujuan dari penelitian ini adalah:

a) Membangun sistem untuk menentukan tingkat partisipasi pemuda dalam program Karang Taruna dilihat dari aspek pengelolaan program.

b) Meningkatkan keakuratan dan kemudahan dalam pengukuran tingkat partisipasi pemuda dalam program Karang Taruna dilihat dari aspek pengelolaan program yang didasarkan pada kriteria dan bobot yang telah ditentukan.

c) Mengimplementasikan logika fuzzy infrence system Mamdani yang dapat digunakan untuk sistem pengukuran tingkat partisipasi pemuda dalam program Karang Taruna dilihat dari aspek pengelolaan program.

d) Mengetahui tingkat partisipasi pemuda dalam program Karang Taruna dilihat dari aspek pengelolaan program.

\subsection{Manfaat}

Manfaat dari penelitian ini adalah:

a) Penelitian ini diharapkan dapat menambah ilmu pengetahuan partisipasi pemuda dalam program Karang Taruna.

b) Bagi pemuda, diharapkan dapat berpartisipasi dalam program Karang Taruna yang diselenggarakan.

\section{METODOLOGI PENELITIAN}

\subsection{Pengertian Fuzzy Logic}

Sebelum munculnya teori fuzzy logic dikenal sebuah logika tegas (crisp logic) yang memiliki nilai benar dan salah secara tegas. Sebaliknya fuzzy logic adalah suatu logika yang memiliki nilai kekaburan atau kesamaran (fuzzyness) antara benar dan salah. Dalam teori fuzzy logic suatu nilai bisa bernilai benar dan salah secara bersamaan. Namun berapa besar kebenaran dan kesalahan suatu nilai tergantung pada bobot keanggotaan yang dimilikinya. Orang yang belum mengenal fuzzy logic pasti akan mengira bahwa fuzzy logic adalah suatu yang amat rumit dan tidak menyenangkan. Namun, sekali orang mengenalnya, ia pasti akan sangat tertarik dan akan menjadi pendatang baru untuk ikut serta mempelajarinya. Fuzzy logic dikatakan sebagai logika baru yang lama, sebab ilmu tentang fuzzy logic modern dan metodis baru ditemukan beberapa tahun yang lalu, padahal sebenarnya konsep tentang fuzzy logic itu sendiri sudah ada pada diri kita sejak lama. Fuzzy logic adalah suatu cara yang tepat untuk memetakan suatu ruang input ke dalam suatu ruang output [6].

\subsection{LogikaFuzzy Infrence System Mamdani}

Logika fuzzy infrence system Mamdani sering juga dikenal dengan nama Metode Max-Min. Metode ini diperkenalkan oleh EbrahimMamdani pada tahun 1975. Untuk mendapatkan output, diperlukan 4 tahapan: 
a) Pembentukan himpunan fuzzy. Menentukan variabel fuzzy dan himpunan fuzzinya. Kemudian tentukan derajat keanggotaan antara data masukan fuzzy dengan himpunan fuzzy yang telah didefenisikan untuk setiap variabel masukan sistem dari setiap aturan fuzzy.

b) Aplikasi fungsi implikasi pada logikafuzzy infrence system Mamdani. Fungsi implikasi yang digunakan adalah min. Hasil implikasi fuzzy dari setiap aturan ini kemudian digabungkan untuk menghasilkan keluaran infrensi fuzzy.

c) Komposisi Aturan (rule). Tidak seperti penalaran monoton, apabila sistem terdiri dari beberapa aturan, maka infrensi diperoleh dari kumpulan dan korelasi antar aturan. Ada 3 metode yang digunakan dalam melakukan inferensi sistem fuzzy, yaitu: max, additive dan Jumlah babilistik OR.

d) Penegasan (defuzzy). Input dari Proses defuzzifikasi adalah suatu himpunan fuzzy yang diperoleh dari komposisi aturan-aturan fuzzy, sedangkan output yang dihasilkan merupakan suatu bilangan pada domain himpunan fuzzy tersebut.

Motivasi utama teori fuzzy logic adalah memetakan sebuah ruang input ke dalam ruang output dengan menggunakan IF-THEN Rule. Pemetaan dilakukan dalam suatu FIS, urutan rule bisa sembarang. FIS mengevaluasi semua rule secara simultan untuk menghasilkan kesimpulan. Oleh karenanya, semua rule harus didefinisikan lebih dahulu sebelum kita membangun sebuah FIS yang akan digunakan untuk menginterpretasikan semua rule tersebut. Mekanisme dalam FIS bisa dirangkum yaitu: FIS adalah sebuah metode yang menginterpretasikan harga-harga dalam vektor input, menarik kesimpulan berdasarkan sekumpulan IF-THEN rule yang diberikan, dan kemudian menghasilkan vektor output [7].

\subsection{Partisipasi}

Partisipasi adalah keterlibatan spontan dengan kesadaran yang disertai tanggung jawab terhadap kepentingan kelompok untuk mencapai tujuan bersama. Partisipasi masyarakat mempunyai fungsi yang sangat penting dalam pemerintahan, karena tanpa adanya partisipasi masyarakat, maka penyelenggaraan pemerintahan tidak akan berjalan secara maksimal. Partisipasi terbentuk apabila adanya keikutsertaan masyarakat terhadap kegiatan atau program yang diberikan oleh pemerintah.

\subsection{Pemuda}

Pemuda adalah warga negara Indonesia yang memasuki periode penting pertumbuhan dan perkembangan yang berusia 16 (enam belas) sampai 30 (tigapuluh) tahun.

\subsection{Karang Taruna}

Karang Taruna adalah organisasi sosial kemasyarakatan sebagai wadahdan sarana pengembangan setiap anggota masyarakat yang tumbuh danberkembang atas dasar kesadaran dan tanggung jawab sosial dari, oleh dan untukmasyarakat terutama generasi muda di wilayah desa / kelurahan atau komunitasadat sederajat terutama bergerak di bidang penyelenggaraan kesejahteraan sosial.

\section{HASIL PENELITIAN DAN PEMBAHASAN}

Partisipasi pemuda dalam program karang taruna desa adalah sesuatu aktifitas untuk membangkitkan perasaan diikutsertakan dalam kegiatan organisasi atau ikut sertanya individu dengan kesadaran diri dalam suatu kegiatan yang bersifat positif untuk mengembangkan tujuan bersama yang membangun di masyarakat. Hal tersebut sesuai dengan pendapat seorang ilmuan yang bernama Keith Davis mengemukakan definisinya tentang partisipasi sebagai berikut, partisipasi dapat didefinisikan sebagai keterlibatan mental atau pikiran atau moral atau perasaan di dalam situasi kelompok yang mendorong untuk memberikan sumbangan kepada kelompok dalam usaha mencapai tujuan serta turut bertanggungjawab terhadap usaha yang bersangkutan [8].

Berdasarkan pendapat tersebut, maka partisipasi itu tidak berdasarkan keterlibatan secara fisik dalam pekerjaannya tetapi menyangkut keterlibatan diri seseorang, sehingga akan menimbulkan tanggung jawab dan sumbangan yang besar terdapat kelompok. Seseorang yang berpartisipasi sebenarnya mengalami keterlibatan dirinya/ egonya yang sifatnya lebih daripada keterlibatan dalam pekerjaan atau tugas saja, dengan keterlibatan dirinya berarti keterlibatan pikiran dan perasaannya. Berdasarkan pernyataan tersebut, maka ada tiga buah unsur penting dalam partisipasi yaitu:

a) Partisipasi merupakan suatu keterlibatan mental dan perasaan, lebih dari semata-mata atau hanya keterlibatan secara jasmaniah.

b) Ketersediaan memberi sesuatu sumbangan kepada usaha mencapai tujuankelompok, ini berarti terdapat rasa senang, kesukarelaan untuk membantu kelompok. 
c) Dalam partisipasi harus ada tanggung jawab, unsur tanggung jawab ini merupakan segi yang menonjol dari rasa menjadi anggota.

Dari uraian jelaslah bahwa partisipasi menyangkut keterlibatan diri/ ego dan tidak semata-mata keterlibatan fisik dalam pekerjaan atau tugas saja, dan ketiga unsur partisipasi tersebut di dalam realitanya tidak akan terpisahkan satu sama lain, tetapi akan saling menunjang. Dalam realitasnya, terutama dalam kehidupan bermasyarakat, berbangsa dan bernegara, istilah partisipasi ini sering dikaitkan dengan usaha di dalam mendukung program pembangunan. Partisipasi mengandung tiga pengertian, yaitu: partisipasi berarti turut memikul beban pembangunan; menerima kembali hasil pembangunan dan bertanggungjawab terhadapnya dan partisipasi berarti terwujudnya kreativitasnya dan otoaktifitas.

\subsection{Partisipasi Dalam Perencanaan}

Berdasarkan hasil penelitian yang dilakukan oleh peneliti, partisipasi dalam perencanaan pada program karang taruna, yakni masyarakat khususnya pemuda dan remaja turut serta atau ikut andil dalam kegiatan merencanakan program, rekrutmen atau pemilihan anggota, serta pembentukan program yang akan dijalankan agar program kegiatan dapat diterima oleh masyaraka, sehingga pemuda dan remaja mengetahui secara jelas bagaimana awal perencanaan program dilakukan. Tanpa adanya campur tangan masyarakat khususnya pemuda dan remaja program tidak akan berhasil atau tidak akan berjalan dengan lancar. Partisipasi masyarakat menjadi penting dalam setiap perencanaan program dan kegiatan sosial, karena:

a) Merupakan suatu sarana untuk memperoleh informasi mengenai kondisi, kebutuhan dan sikap masyarakat setempat. Tanpa informasi ini, maka program tidak akan berhasil.

b) Masyarakat akan lebih antusias terhadap program/ kebijakan pembangunan, apabila mereka dilibatkan dalam perencanaan dan persiapan, sehingga mereka akan menganggap bahwa program atau kebijakan tersebut adalah mereka. Hal ini perlu untuk menjamin program diterima oleh masyarakat, khususnya dalam program yang bertujuan untuk merubah masyarakat dalam cara berfikir, merasa dan bertindak.

c) Banyak negara-negara yang menganggap bahwa partisipasi masyarakat merupakan "hak demokrasi yang bersifat dasar” dimana masyarakat harus dilibatkan dalam proses pembangunan dimaksudkan untuk memberi keuntungan pada manusia

\subsection{Partisipasi Dalam Pelaksanaan}

Partisipasi dalam pelaksanaan pada program karang taruna yaitu turut sertanya masyarakat pada pelaksanaan program kegiatan khususnya pemuda dan remaja agar bisadijadikan pelaku pelaksana program atau penanggung jawab disetiap kegiatannya. Dan juga mengetahui sarana dan prasarana yang digunakan dan dapat mendukung pada pelaksanaan program kegiatan. Partisipasi pada tahap ini maksudnya adalah pelibatan seseorang pada tahap pelaksanaan pekerjaan suatu proyek [9]. Masyarakat disini dapat memberikan tenaga, uang atau pun material/ barang serta ide-ide sebagai salah satu wujud partisipasinya pada pekerjaan tersebut.

\subsection{Partisipasi Dalam Pemanfaatan}

Partisipasi pada tahap ini dalam program karang taruna yaitu, ikut sertanya pemuda dan remaja dalam memanfaatkan program kegiatan dengan cara meningkatkan potensi yang dimiliki oleh individu. Kemudian pihak karang taruna memelihara program dan mengembangkan program dengan cara terus melakukan sosialisasi dalam lingkup anggota atau pun dalam lingkup masayarakat. Partisipasi pada tahap ini maksudnya adalah pelibatan seseorang pada tahap pemanfaatan suatu proyek setelah proyek tersebut selesai dikerjakan. Partisipasi masyarakat pada tahap ini berupa tenaga dan uang untuk mengoperasikan dan memelihara proyek yang telah dibangun

\subsection{Penerapan Logika}

Dalam penyusunan penerapan logika fuzzy infrence system Mamdani untuk pengukuran tingkat partisipasi pemuda dalam program Karang Taruna ini terdapat beberapa langkah yang harus dilakukan untuk mendapatkan data yang valid dalam penyusunannya.

Setelah dilakukan perhitungan dan percobaan, maka didapatlah hasil pengukuran tingkat partisipasi pemuda dalam program Karang Taruna dengan menerapkan logika fuzzy infrence system Mamdani dengan Matlab. Berikut ini cara untuk menentukan himpunan Fuzzy : 
a) Variabel Partisipasi dalam Perencanaan

Variabel input Partisipasi dalam Perencanaan yakni masyarakat khususnya pemuda dan remaja turut serta atau ikut andil dalam kegiatan merencanakan program, rekrutmen atau pemilihan anggota, serta pembentukan program yang akan dijalankan agar program kegiatan dapat diterima oleh masyarakat. Range dan domain dari variabel Partisipasi dalam Perencanaan dapat terlihat pada tabel 1 di bawah ini.

Tabel 1. Partisipasi dalam perencanaan

\begin{tabular}{cccc}
\hline No & Himpunan & Range & Domain \\
\hline 1 & Kurang & $1-10$ & $0-4$ \\
2 & Sedang & $1-10$ & $3-7$ \\
3 & Baik & $1-10$ & $6-10$ \\
\hline
\end{tabular}

Variabel Partisipasi dalam Perencanaan dibagi menjadi 3 himpunan fuzzy yaitu: Kurang, Sedang, dan Bagus. Himpunan fuzzy Kurang akan memiliki domain [0 - 4] dimana derajat keanggotaan Kurang tertinggi (=1) terletak pada angka 0 - 3. Himpunan fuzzy Sedang memiliki domain [3 - 7] dimana derajat keanggotaan Sedang tertinggi $(=1)$ terletak pada nilai 5. Himpunan fuzzy Bagus akan memiliki domain [6 - 10] dimana derajat keanggotaan Bagus tertinggi (=1) terletak pada angka $\geq 7$. Variabel Partisipasi dalam Perencanaan dipresentasikan dengan fungsi keanggotaan bahu dan segitiga. Hasil pengolahan himpunan dengan program Matlab dapat terlihat seperti pada gambar 1 di bawah ini.

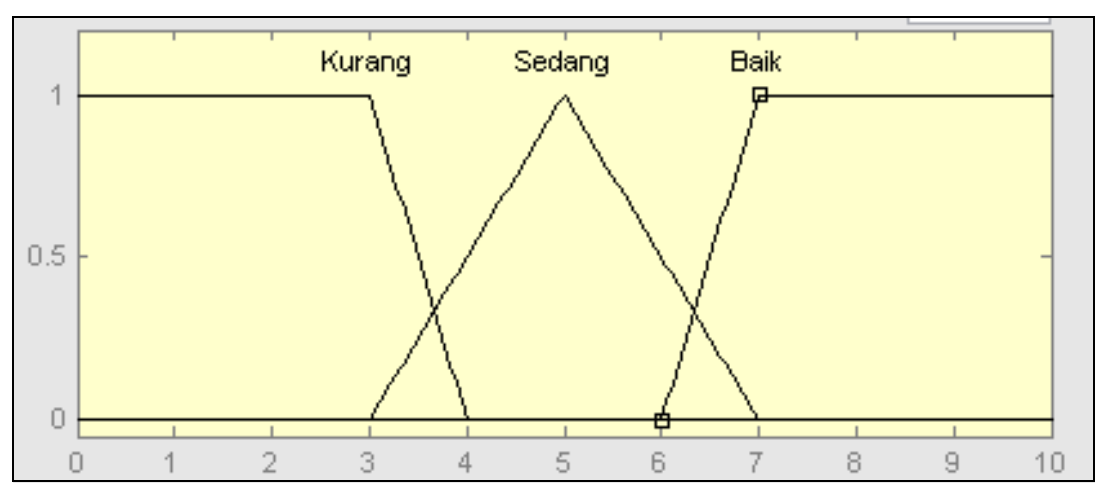

Gambar 1. Grafik Partisipasi Dalam Perencanaan

Dan persamaannya.

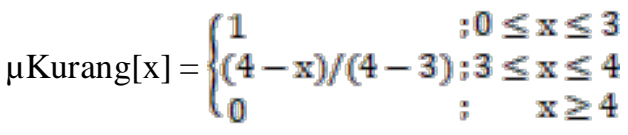

$$
\begin{aligned}
& \mu \text { Sedang }[x]= \begin{cases}(x-3) /(4-3) ; & 3 \leq x \leq 4 \\
(7-x) /(4-3) ; & 4 \leq x \leq 7 \\
0 & ; x \leq 3 \text { ataux } \geq 7\end{cases} \\
& \mu \operatorname{Baik}[x]=\left\{\begin{array}{llc}
0 & ; & x \leq 6 \\
(x-6) /(10-6) ; & 6 \leq x \leq 7 \\
1 & ; 7 \leq x \leq 10
\end{array}\right.
\end{aligned}
$$

b) Variabel Partisipasi dalam Pelaksanaan

Variabel input Partisipasi dalam Pelaksanaan yaitu turut sertanya masyarakat pada pelaksanaan program kegiatan khususnya pemuda dan remaja agar bisa dijadikan pelaku pelaksana program atau penanggung jawab di setiap kegiatannya. Range dan domain dari variabel Partisipasi dalam Pelaksanaan dapat terlihat pada tabel 2 di bawah ini.

Tabel 2. Partisipasi dalam pelaksanaan

\begin{tabular}{cccc}
\hline No & Himpunan & Range & Domain \\
\hline 1 & Kurang & $1-10$ & $0-4$ \\
2 & Sedang & $1-10$ & $3-7$ \\
3 & Baik & $1-10$ & $6-10$ \\
\hline
\end{tabular}


Variabel Partisipasi dalam Pelaksanaan dibagi menjadi 3 himpunan fuzzy yaitu: Kurang, Sedang, dan Bagus. Himpunan fuzzy Kurang akan memiliki domain [0 - 4] dimana derajat keanggotaan Kurang tertinggi (=1) terletak pada angka 0 - 3. Himpunan fuzzy Sedang memiliki domain [3 - 7] dimana derajat keanggotaan Sedang tertinggi $(=1)$ terletak pada nilai 5. Himpunan fuzzy Bagus akan memiliki domain [6 - 10] dimana derajat keanggotaan Bagus tertinggi (=1) terletak pada angka $\geq 7$. Variabel Partisipasi dalam Pelaksanaan dipresentasikan dengan fungsi keanggotaan bahu dan segitiga. Hasil pengolahan himpunan dengan program Matlab dapat terlihat seperti pada gambar 2 di bawah ini.

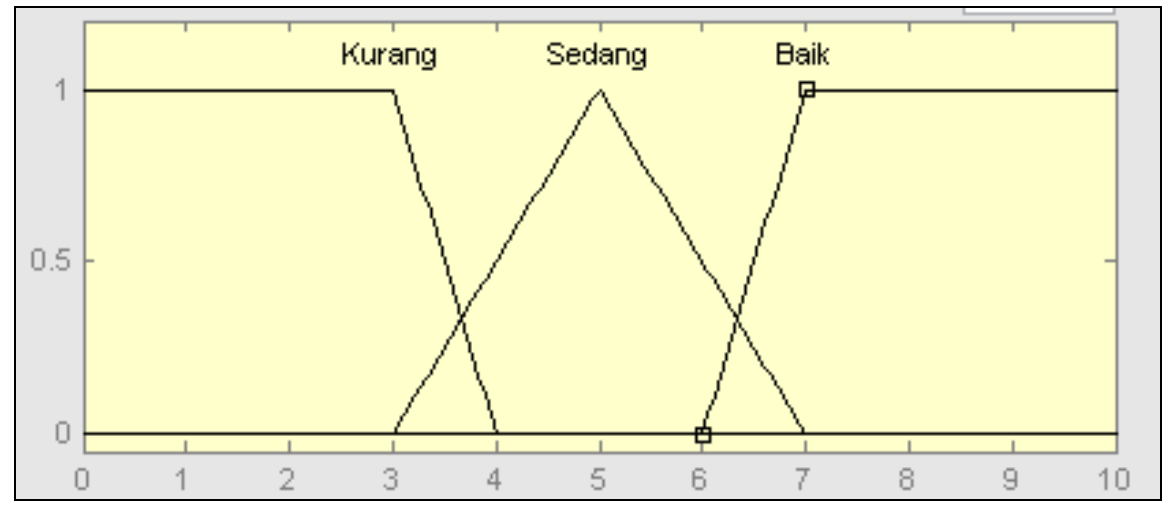

Gambar 2. Grafik Partisipasi Dalam Pelaksanaan

Dan persamaannya.

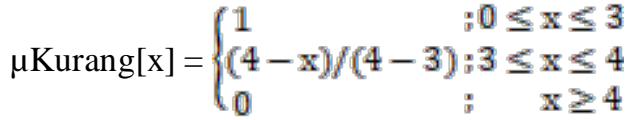

$$
\begin{aligned}
& \mu \text { Sedang }[x]= \begin{cases}(x-3) /(4-3) ; & 3 \leq x \leq 4 \\
(7-x) /(4-3) ; & 4 \leq x \leq 7 \\
0 & ; x \leq 3 \text { ataux } \geq 7\end{cases} \\
& \mu \operatorname{Baik}[x]=\left\{\begin{array}{lrr}
0 & x \leq 6 \\
(x-6) /(10-6) ; & 6 \leq x \leq 7 \\
1 & ; & 7 \leq x \leq 10
\end{array}\right.
\end{aligned}
$$

c) Variabel Partisipasi dalam Pemanfaatan

Variabel input Partisipasi dalam Pemanfaatan yaitu, ikut sertanya pemuda dan remaja dalam memanfaatkan program kegiatan dengan cara meningkatkan potensi yang dimilikioleh individu. Range dan domain dari variabel Partisipasi dalam Pemanfaatan dapat terlihat pada tabel 3 di bawah ini.

Tabel 3. Partisipasi dalam pemanfaatan

\begin{tabular}{cccc}
\hline No & Himpunan & Range & Domain \\
\hline 1 & Kurang & $1-10$ & $0-4$ \\
2 & Sedang & $1-10$ & $3-7$ \\
3 & Baik & $1-10$ & $6-10$ \\
\hline
\end{tabular}

Variabel Partisipasi dalam Pemanfaatan dibagi menjadi 3 himpunan fuzzy yaitu: Kurang, Sedang, dan Bagus. Himpunan fuzzy Kurang akan memiliki domain [0 - 4] dimana derajat keanggotaan Kurang tertinggi (=1) terletak pada angka 0 - 3. Himpunan fuzzy Sedang memiliki domain [3 - 7] dimana derajat keanggotaan Sedang tertinggi $(=1)$ terletak pada nilai 5. Himpunan fuzzy Bagus akan memiliki domain [6 - 10] dimana derajat keanggotaan Bagus tertinggi (=1) terletak pada angka $\geq 7$. Variabel Partisipasi dalam Pemanfaatan dipresentasikan dengan fungsi keanggotaan bahu dan segitiga. Hasil pengolahan himpunan dengan program Matlab dapat terlihat seperti pada gambar 3 di bawah ini. 


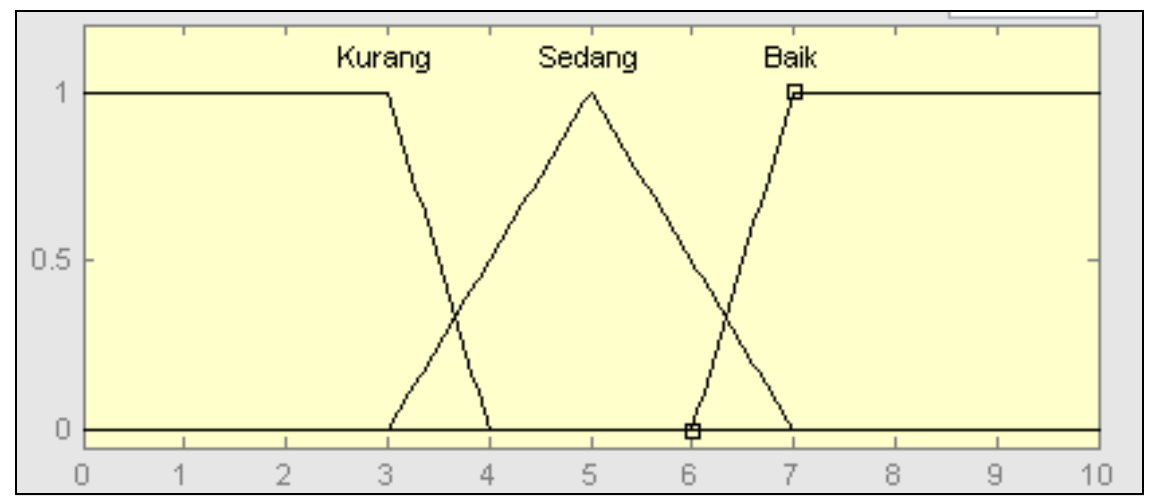

Gambar 3. Grafik Partisipasi Dalam Pemanfaatan

Dan persamaannya.

$$
\begin{aligned}
& \mu \text { Kurang}[x]=\left\{\begin{array}{lr}
1 & ; 0 \leq x \leq 3 \\
(4-x) /(4-3) ; 3 \leq x \leq 4 \\
0 & ; \quad x \geq 4
\end{array}\right. \\
& \mu \text { Sedang }[x]= \begin{cases}(x-3) /(4-3) ; & 3 \leq x \leq 4 \\
(7-x) /(4-3) ; 4 \leq x \leq 7 & ; \\
0 & ; x \leq 3 \text { ataux } \geq 7\end{cases} \\
& \mu \operatorname{Baik}[x]=\left\{\begin{array}{lrr}
0 & x \leq 6 \\
(x-6) /(10-6) ; & 6 \leq x \leq 7 \\
1 & ; 7 \leq x \leq 10
\end{array}\right.
\end{aligned}
$$

\subsection{Proses Mamdani}

Dalam proses mamdani terdapat beberapa tahapan yang harus dilakukan diantaranya:

\subsubsection{Fuzzifikasi}

Fungsi derajat keanggotaan yang digunakan adalah fungsi linier turun, fungsi segitiga dan fungsi linier naik. Berikut adalah Fungsi Derajat Keanggotaan dari semua variabel:

$$
\begin{array}{ll}
\text { HFT }=1 & \text { HFT }=1 \\
\text { PHFT }=0,66 & \text { HFN }=0,66 \\
\text { HFT }=1 & \text { HFT }=0,20 \\
\text { HFT }=0,73 & \text { HFN }=1 \\
\text { HFT }=0,71 & \text { HFT }=1 \\
\text { HFT }=0,66 & \text { HFT }=1 \\
\text { HFT }=1 & \\
\text { HFT }=1 & \text { HFT }=0,75
\end{array}
$$

Keterangan :

HFT (Himpunan Fuzzy Tinggi)

HFN (Himpunan Fuzzy Normal)

\subsubsection{Rules}

Pembentukan rule editor, yaitu tempat dimana rule-rule dikelola, baik itu untuk menambah, menghapus, dan juga mengubah rule. Pada rule editor lah rule dikelola agar nantinya sistem dapat menghasilkan output sesuai dengan input yang dilakukan pada variabel-variabel input. Ruleyang telah ditetapkan memiliki 22 Rule.

\subsubsection{Fungsi Implikasi}

Fungsi implikasi yang digunakan adalah metode min dan rule yang terpengaruh adalah rule 21 dan rule 22.

$$
\begin{aligned}
\alpha_{21}= & \min \{\mu \mathrm{t}(12), \mu \mathrm{t}(12), \mu \mathrm{t}(8), \mu \mathrm{t}(22), \mu \mathrm{t}(14), \mu \mathrm{t}(12), \mu \mathrm{t}(10), \mu \mathrm{t}(6), \mu \mathrm{t}(12), \mu \mathrm{t}(10), \mu \mathrm{t}(10), \\
& \mu \mathrm{t}(16), \mu \mathrm{t}(6), \mu \mathrm{t}(6)\} \\
= & \min (1 ; 0,66 ; 1 ; 0,73 ; 0,71 ; 0,66 ; 0,66 ; 1 ; 1 ; 0,75 ; 1 ; 1 ; 1 ; 1) \\
= & 0,66
\end{aligned}
$$


Berdasarkan fungsi keanggotaan dari variabel output himpunan tinggi, pada saat $\alpha_{21}=0,66$ diperoleh nilai:

$$
\begin{aligned}
& \begin{aligned}
\mu b= & \left(\mathrm{d}_{21}\right)=\alpha_{21} \longrightarrow \frac{\mathrm{d}[21]-8}{7} \\
\mathrm{~d}[21] & \longrightarrow
\end{aligned}=0,66 \\
& \alpha_{22}=\min \{\mu \mathrm{t}(12), \mu \mathrm{t}(12), \mu \mathrm{t}(8), \mu \mathrm{t}(22), \mu \mathrm{t}(14), \mu \mathrm{t}(12), \mu \mathrm{t}(10), \mu \mathrm{t}(6), \mu \mathrm{t}(12), \mu \mathrm{t}(10), \mu \mathrm{t}(10), \\
& \quad \mu \mathrm{t}(16), \mu \mathrm{t}(6), \mu \mathrm{t}(6)\} \\
& \quad=\min (1 ; 0,66 ; 1 ; 0,73 ; 0,71 ; 0,66 ; 0,2 ; 1 ; 1 ; 0,75 ; 1 ; 1 ; 1 ; 1) \\
& \quad=0,2
\end{aligned}
$$
nilai:

Berdasarkan fungsi keanggotaan variabel output himpunan tinggi, pada saat $\alpha 22=0,2$ diperoleh

$$
\begin{aligned}
& \mu \mathrm{b}=\left(\mathrm{d}_{22}\right)=\alpha_{22} \longleftrightarrow \frac{\mathrm{d}[22]-8}{7}=0,2 \\
& \mathrm{~d}[22]=1,4+3=4,4
\end{aligned}
$$

\subsubsection{Komposisi Aturan}

Metode Max digunakan untuk mentukan komposisi aturan. Variabel output, Derajat kebenaran himpunan BAIK

$$
\begin{aligned}
& =\operatorname{Max}\left(\alpha_{21} ; \alpha_{22}\right) \\
& =\operatorname{Max}(0,66 ; 0,2) \\
& =0,66
\end{aligned}
$$

Daerah hasil inferensi tertinggi adalah 0,66 dan terendah 0,2

\subsubsection{Defuzzyfikasi}

Metode yang digunakan untuk fuzzyfikasi adalah centroid.

$$
\begin{aligned}
& \mu(\mathrm{x})=\left\{\begin{array}{c}
0,2 ; 4,4 \leq d_{21} \leq 7,62 \\
0,66 ; 7,62 \leq d_{21} \leq 10
\end{array}\right. \\
& \mathrm{M} 1 \quad=\int_{4,4}^{7,62}(0,2) x d x \\
& =0,\left.1 \mathrm{x}^{2}\right|_{4,4} ^{7,62}=5,81-1,9=3,91 \\
& \mathrm{M} 2 \quad=\int_{7,62}^{10}(0,66) x d x \\
& \text { L1 } \quad=0,2 \quad(7,62-4,4)=0,6 \\
& \text { L2 } \quad=0,66(10-7,62)=1,5
\end{aligned}
$$

Nilai crisp output dihitung dengan:

$$
\mathrm{z}^{*} \quad=\frac{M_{1}+M_{2}}{A_{1}+A_{2}}=\frac{14+2,91}{0,6+1,5}=8,53
$$

Melalui hasil pengolahan dengan pendekatan metode fuzzy.Kita dapat mengetahui tingkat partisipasi pemuda dalam program Karang Taruna secara cepat dan tepat.

\subsection{Implementasi Program}

Pengimplementasian program pada penelitian ini menggunakan bahasa pemrograman Matlab dalam menerapkan logika fuzzy infrence system Mamdani untuk mengetahui tingkat partisipasi pemuda dalam program Karang Taruna. Berikut adalah hasil implementasi logika fuzzy infrence system Mamdani. Tahapan-tahapan yang perlu dilakukan diantaranya:

a) Pembentukan rule editor, yaitu tempat dimana rule-rule dikelola, baik itu untuk menambah, menghapus, dan juga mengubah rule. Pada rule editor lah rule dikelola agar nantinya sistem dapat menghasilkan output sesuai dengan input yang dilakukan pada variabel-variabel input. 
b) Pembuatan prototipe yang merupakan bagian dari produk yang mengekspresikan logika maupun fisik antarmuka eksternal yang ditampilkan [10]. Tampilan Graphic User Interface (GUI) yang merupakan tampilan hasil eksekusi program dan tempat memasukkan nilai pada tiap-tiap variabel input. Setelahnya dapat dilihat hasil atau output dari program tersebut. Tampilan program tingkat partisipasi pemuda dalam program Karang Taruna dapat dilihat pada gambar 4 di bawah ini.

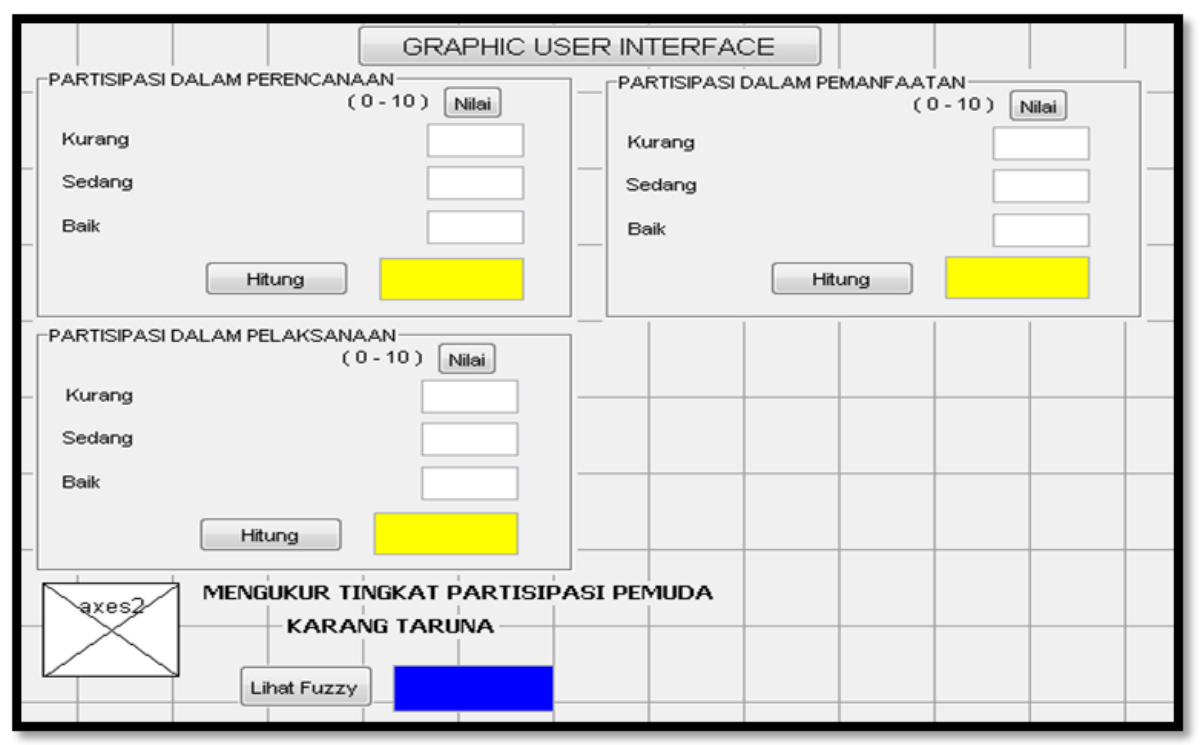

Gambar 4. Graphic User Interface

\section{KESIMPULAN}

Hasil dari penelitian ini dapat disimpulkan antara lain:

a) Penerapan logika fuzzy infrence system Mamdani untuk mengetahui tingkat partisipasi pemuda dalam program Karang Taruna dapat menggunakan Matlab R2009b dalam pemodelan sistemnya yang biasanya Matlab memang digunakan sebagai pendukung penelitian, sehingga bisa dikembangka dengan menggunakan alat bantu lain seperti Delphi, PHP, Visual Basic, Java, dan lain sebagainya agar nantinya bisa didapatkan interface yang lebih interaktif bagi user dan dapat digunakan untuk halayak luas.

b) Penerapan logika fuzzy infrence system Mamdani disini hanya sebatas mengetahui tingkat partisipasi pemuda dalam program Karang Taruna tidak sampai pada pengambilan keputusan.

c) Partisipasi pemuda dalam program Karang Taruna menggunakan tiga tahap partisipasi, yaitu partisipasi dalam perencanaan; partisipasi dalam pelaksanaan; dan partisipasi dalam pemanfaatan.

\section{DAFTAR PUSTAKA}

[1] Wenti. (2013). Eksistensi Karang Taruna. Ejournal Pemerintahan Integratif.

[2] Hilda, Ismay. (2011). Peran Karang Taruna dalam Pembinaan Generasi. Tesis.

[3] Yusuf, Ilma Fatimah. (2010). Peran Pemuda Dalam Pengembangan Eduwisata Energi Terbarukan Dan Implikasinya Terhadap Ketahanan Keluarga. Jurnal Ketahanan Nasional UGM.

[4] Marimin, dan Nurul. (2010) Aplikasi Teknik Pengambilan Keputusan dalam Manajemen Rantai Pasok, Bogor: IPB Press.

[5] Efraim Turban, Jay E. Aronson, and Ting-Peng Liang. (2005). Decision Support System And Intelligent System-7th Ed. Pearson Education, New Jersey: Inc. Upper Saddle River.

[6] Kusumadewi, Sri, et al. (2006). Fuzzy Multi-Attribute Decision Making (Fuzzy MADM).Yogjakarta: Graha Ilmu.

[7] Eng, Agus Naba. (2009). Belajar Cepat Fuzzy Logic menggunakan Matlab. Yogyakarta: Andi Offset.

[8] Sastropoetro, Santoso R.A. (1988). Partisipasi, Komunikasi, Persuasi Dan Disiplin Dalam Pembangunan Nasional. Bandung: Alumni.

[9] Slamet, Y.(1994). Pembangunan Masyarakat Berwawasan Partisipasi. Surakarta: UNS Press.

[10] Simarmata, Janner.(2010). Rekayasa Perangkat Lunak. Yogyakarta: Andi Offset. 